\title{
Review: NIR Spectroscopy as a Suitable Tool for the Investigation of the Horticultural Field
}

\author{
Tiziana M.P. Cattaneo * and Annamaria Stellari \\ Council for Agricultural Research and Economics (Research Centre for Engineering and AgroFood \\ Processing-CREA-IT), Via Venezian 26, 20133 Milan, Italy; annamaria.stellari@crea.gov.it \\ * Correspondence: tiziana.cattaneo@crea.gov.it; Tel.: +39-02-239-557-212
}

Received: 25 July 2019; Accepted: 28 August 2019; Published: 1 September 2019

\begin{abstract}
The last 10 years of knowledge on near infrared (NIR) applications in the horticultural field are summarized. NIR spectroscopy is considered one of the most suitable technologies of investigation worldwide used as a nondestructive approach to monitoring raw materials and products in several fields. There are different types of approaches that can be employed for the study of key issues for horticultural products. In this paper, an update of the information collected from the main specific International Journals and Symposia was reported. Many papers showed the use of NIR spectroscopy in the horticultural field, and the literature data were grouped per year, per product, and per application, such as studies of direct (chemical composition) and indirect (physical and sensorial) properties $(\mathrm{P})$, process control (PC), and authenticity and classification studies (AC). A mention was made of a recent innovative approach that considers the contribution of water absorption in the study of biological systems.
\end{abstract}

Keywords: NIR spectroscopy; review; nondestructive techniques; horticultural products

\section{Introduction}

The application of near infrared (NIR) spectroscopy to the horticultural field still attracts considerable attention. The three last dedicated reviews, available in the literature [1-3], in books relating to the spectroscopic sector, were published before 2010, focusing their attention on adequate ways to analyze fresh horticultural products, and scheduling big tables to highlight the product category, the considered parameters, and the used instrumentation. In particular, Saranwong and Kawano [2] reported exhaustive information on the basic components (light source, detector, etc.) of NIR spectroscopy setup, illustrating several commercially available solutions to reach specific objectives, which are still useful. A short paper [4], published in 2016, while containing traditional and innovative concepts on the trend of NIR applications in the horticultural sector, also mentions bibliographic documents prior to 2010. For this reason, it is time to also update our knowledge of NIR spectroscopy in journals more dedicated to the agronomic field with the aim to help scientists and technicians, operating at both the public and private level, in the collection of useful information about the application of this fast technology, its ability to detect several quality attributes, and for a rapid online sorting of products into quality categories. Today, the development of small portable NIR systems, the improvement of acquisition and processing software, and the progresses in miniature electronics allow an easier approach to NIR spectroscopy more than in the past. In this context, this paper was assembled to update information about the new developments and uses of NIR spectroscopy as a useful tool for measuring internal quality characteristics of horticultural products (fruit and vegetables) in the field, during postharvest and storage, at the market, while also exploring some new applications and including practical experiences and outcomes from an industrial perspective. Seeds, trees, and other specific classes were not considered. The literature data were grouped per year, per product, 
and per application, such as studies of direct and indirect properties (P), process control (PC), and authenticity and classification studies (AC).

\section{Collection of Literature Data}

The update of the information reported here was done by checking the scientific papers published since 2009 in the main specific International Journals and Symposia, while some papers were also recovered in International Journals focused on food science. Unfortunately, the proceedings of the Asian Symposia and Conferences could not be added to this review because they are written in their original language, which is very difficult to translate. The aim of this paper was to make available a robust list of papers for a rapid consultation, allowing a simple recovery of dedicated references. Table 1 reports the list of the total papers reviewed; references were grouped by product of interest/assigned class on the basis of the type of determinations made; year of publication (as total references/year and reference/class); total number of papers; and the reference number, as reported inside the "References" paragraph, shown in the last column. In this way, the whole set of information can be checked using Table 1, as a summary table for easy consultation. A first analysis of the data reported in Table 1 allowed us to observe how, out of 160 bibliographic references [5-30,30-165], $80 \%$ concerned investigations and studies on fruit $[5,7,13,15-30,33-38,40-43,45-59,64,67-93,102-104$, $106,108,111-121,123-135,141-143,145-162]$, of which $30 \%$ were carried out on apples, with a total of 41 referred papers [21-27,33,38,46,58,59,80-82,84-92,113,123-134,146,150,153,155]. Thus, it appears that many groups of researchers have considered the apple as a model fruit, suitable for testing the applications of NIR spectroscopy in the horticultural sector. About $50 \%$ of the papers were focused on the use of NIR for process monitoring and authentication and classification studies [64-145,157-161]. Although olive is a fruit, there is usually a tendency to consider it as a vegetable because olives are not consumed after a meal but as a side dish or appetizer. Using this meaning, olives have been, among vegetables, the most studied species [94-96,136-140], with papers classified in class groups (PC) and (AD); the last dedicated review for this kind of vegetable was published in 2015 [96]. The available literature has been growing from 2013 to today, and 20 papers have been published already in 2019, indicating a parallel growth of interest for this kind of technology in the horticultural field. 
Table 1. List of papers reporting near infrared (NIR) applications in the horticultural field.

\begin{tabular}{|c|c|c|c|c|c|c|c|c|c|c|c|c|c|}
\hline \multirow[t]{2}{*}{ Product/Class } & \multicolumn{11}{|c|}{ Year of Publication } & \multirow[t]{2}{*}{ \# of Papers } & \multirow[t]{2}{*}{ Reference Number } \\
\hline & 2009 & 2010 & 2011 & 2012 & 2013 & 2014 & 2015 & 2016 & 2017 & 2018 & 2019 & & \\
\hline acerola & & & & & & & 1 & 2 & 1 & & & 4 & \\
\hline $\mathrm{P}$ & & & & & & & 1 & 1 & & & & 2 & {$[5,41]$} \\
\hline PC & & & & & & & & 1 & & & & 1 & [64] \\
\hline $\mathrm{AC}$ & & & & & & & & 1 & & & & 1 & [104] \\
\hline apple & 3 & 3 & & 2 & 4 & 3 & 4 & 2 & 2 & 8 & 10 & 41 & \\
\hline $\mathrm{P}$ & 2 & & & 1 & 1 & 1 & 1 & 2 & 1 & 1 & 4 & 14 & $\begin{array}{c}{[21-27,33,38]} \\
46,58-59,146,151\end{array}$ \\
\hline PC & & 2 & & & 2 & 1 & 2 & & & 3 & 3 & 13 & $\begin{array}{c}{[80-82,84-92]} \\
{[153]}\end{array}$ \\
\hline $\mathrm{AC}$ & 1 & 1 & & 1 & 1 & 2 & 1 & & 1 & 4 & 2 & 14 & $\begin{array}{c}{[113,123-134]} \\
{[155]}\end{array}$ \\
\hline apricot & 1 & & & & & & & & & & & 1 & \\
\hline $\mathrm{P}$ & 1 & & & & & & & & & & & 1 & [42] \\
\hline asparagus & & & & & & & & & & & 1 & 1 & \\
\hline $\mathrm{AC}$ & & & & & & & & & & & 1 & 1 & [107] \\
\hline avocado & 1 & & 1 & & & & & & & & & 2 & \\
\hline $\mathrm{P}$ & 1 & & & & & & & & & & & 1 & [7] \\
\hline $\mathrm{AC}$ & & & 1 & & & & & & & & & 1 & [108] \\
\hline bananito & & & & & & & & 1 & & 1 & & 2 & \\
\hline $\mathrm{P}$ & & & & & & & & & & 1 & & 1 & {$[8]$} \\
\hline PC & & & & & & & & 1 & & & & 1 & [68] \\
\hline blueberry & 1 & & & & & 1 & 1 & & & & & 3 & \\
\hline $\mathrm{P}$ & & & & & & 1 & 1 & & & & & 2 & {$[16,28]$} \\
\hline $\mathrm{AC}$ & 1 & & & & & & & & & & & 1 & [135] \\
\hline cassava & & & & & 1 & & & & & & & 1 & \\
\hline $\mathrm{P}$ & & & & & 1 & & & & & & & 1 & [20] \\
\hline cherry & & & & & & & & & & 2 & & 2 & \\
\hline P & & & & & & & & & & 2 & & 2 & {$[43,148]$} \\
\hline cherry tomato & 1 & & & & & & & & & & & 1 & \\
\hline $\mathrm{P}$ & 1 & & & & & & & & & & & 1 & [31] \\
\hline citrus & 1 & & & & 1 & & 1 & 1 & 2 & & 1 & 8 & \\
\hline PC & & & & & 1 & & & & & & & 1 & {$[74]$} \\
\hline $\mathrm{AC}$ & 1 & & & 1 & & & 1 & 1 & 2 & & 1 & 7 & {$[106,114-118,162]$} \\
\hline
\end{tabular}


Table 1. Cont.

\begin{tabular}{|c|c|c|c|c|c|c|c|c|c|c|c|c|c|}
\hline \multirow[t]{2}{*}{ Product/Class } & \multicolumn{11}{|c|}{ Year of Publication } & \multirow[t]{2}{*}{ \# of Papers } & \multirow[t]{2}{*}{ Reference Number } \\
\hline & 2009 & 2010 & 2011 & 2012 & 2013 & 2014 & 2015 & 2016 & 2017 & 2018 & 2019 & & \\
\hline cynar & & & & & & & & 1 & & & & 1 & \\
\hline $\mathrm{AC}$ & & & & & & & & 1 & & & & 1 & [109] \\
\hline fruit & 2 & & 1 & & 3 & 4 & & 2 & 2 & 1 & 1 & 16 & \\
\hline $\mathrm{P}$ & 1 & & 1 & & & 4 & & 1 & 2 & & & 9 & {$[10,11,13,45,47,49,51,128,147]$} \\
\hline PC & 1 & & & & 2 & & & 1 & & & 1 & 5 & {$[69-72,83]$} \\
\hline $\mathrm{AC}$ & & & & & 1 & & & & & 1 & & 2 & {$[111,112]$} \\
\hline fruit and vegetables & & & & & & 1 & & & 1 & 1 & & 3 & \\
\hline $\mathrm{P}$ & & & & & & & & & & 1 & & 1 & [14] \\
\hline PC & & & & & & 1 & & & & & & 1 & [97] \\
\hline $\mathrm{AC}$ & & & & & & & & & 1 & & & 1 & [163] \\
\hline garlic & & & & & & & & 1 & & & & 1 & \\
\hline $\mathrm{P}$ & & & & & & & & 1 & & & & 1 & [6] \\
\hline grape & 2 & 1 & & 1 & 1 & 1 & & 2 & & 1 & 1 & 10 & \\
\hline $\mathrm{P}$ & 2 & 1 & & 1 & & 1 & & & & & 1 & 6 & {$[34-37,151,152]$} \\
\hline PC & & & & & & & & 2 & & 1 & & 3 & {$[102,103,154]$} \\
\hline $\mathrm{AC}$ & & & & & 1 & & & & & & & 1 & [145] \\
\hline kiwi & 1 & & & & & & & & 1 & & & 2 & \\
\hline $\mathrm{P}$ & 1 & & & & & & & & & & & 1 & [52] \\
\hline PC & & & & & & & & & 1 & & & 1 & [73] \\
\hline macadamia & & & & & & & & & & & 1 & 1 & \\
\hline PC & & & & & & & & & & & 1 & 1 & [93] \\
\hline mandarin & 2 & & & & & 1 & & 1 & & & & 4 & \\
\hline $\mathrm{P}$ & 2 & & & & & & & 1 & & & & 3 & {$[17,53,149]$} \\
\hline $\mathrm{AC}$ & & & & & & 1 & & & & & & 1 & [158] \\
\hline mango & 6 & 1 & & 1 & 2 & 1 & & 1 & 3 & 1 & 1 & 17 & \\
\hline P & 1 & & & & 1 & & & 1 & 3 & & & 6 & {$[18,19,54-57]$} \\
\hline PC & 2 & 1 & & 1 & 1 & & & & & 1 & 1 & 7 & {$[67,75-79,161]$} \\
\hline $\mathrm{AC}$ & 3 & & & & & 1 & & & & & & 4 & {$[119-121,159]$} \\
\hline eggplant & & & & & & & & & & 1 & & 1 & \\
\hline AC & & & & & & & & & & 1 & & 1 & [122] \\
\hline olive & & 1 & & 1 & & 1 & 3 & & 1 & 1 & & 8 & \\
\hline PC & & & & & & & 2 & & & 1 & & 3 & [94-96] \\
\hline $\mathrm{AC}$ & & 1 & & 1 & & 1 & 1 & & 1 & & & 5 & [13-140] \\
\hline onion & & & & & & & & & & 1 & & 1 & \\
\hline
\end{tabular}


Table 1. Cont.

\begin{tabular}{|c|c|c|c|c|c|c|c|c|c|c|c|c|c|}
\hline \multirow[t]{2}{*}{ Product/Class } & \multicolumn{11}{|c|}{ Year of Publication } & \multirow[t]{2}{*}{ \# of Papers } & \multirow[t]{2}{*}{ Reference Number } \\
\hline & 2009 & 2010 & 2011 & 2012 & 2013 & 2014 & 2015 & 2016 & 2017 & 2018 & 2019 & & \\
\hline $\mathrm{P}$ & & & & & & & & & & 1 & & 1 & {$[44]$} \\
\hline orange & & & & & & & & & & 1 & & 1 & \\
\hline $\mathrm{P}$ & & & & & & & & & & 1 & & 1 & {$[40]$} \\
\hline palm fruit & & & & 1 & & & & & & & & 1 & \\
\hline $\mathrm{P}$ & & & & 1 & & & & & & & & 1 & [29] \\
\hline papaya & & & & & & & & & & 2 & & 2 & \\
\hline $\mathrm{P}$ & & & & & & & & & & 1 & & 1 & [30] \\
\hline passion fruit & & & & & & 1 & & & & 1 & & 2 & \\
\hline $\mathrm{P}$ & & & & & & 1 & & & & 1 & & 2 & {$[15,50]$} \\
\hline peach & & & & & & & & & 1 & 1 & & 2 & \\
\hline $\mathrm{AC}$ & & & & & & & & & 1 & 1 & & 2 & {$[142,143]$} \\
\hline pear & 1 & & & & 1 & & & & & 1 & & 3 & \\
\hline $\mathrm{P}$ & & & & & & & & & & 1 & & 1 & [12] \\
\hline PC & & & & & 1 & & & & & & & 1 & [160] \\
\hline $\mathrm{AC}$ & 1 & & & & & & & & & & & 1 & [141] \\
\hline pineapple & & & & & & & 1 & & & & & 1 & \\
\hline $\mathrm{P}$ & & & & & & & 1 & & & & & 1 & [165] \\
\hline pomegranate & & & & & & & & & & 2 & & 2 & \\
\hline $\mathrm{P}$ & & & & & & & & & & 1 & & 1 & {$[48]$} \\
\hline $\mathrm{AC}$ & & & & & & & & & & 1 & & 1 & [156] \\
\hline potato & & & & & & & & 1 & & & & 1 & \\
\hline $\mathrm{P}$ & & & & & & & & 1 & & & & 1 & {$[60]$} \\
\hline rape & & & & & & & & & & & 1 & 1 & \\
\hline $\mathrm{P}$ & & & & & & & & & & & 1 & 1 & [32] \\
\hline spinach & & & & & & & & & & 1 & 1 & 2 & \\
\hline $\mathrm{P}$ & & & & & & & & & & 1 & & 1 & [62] \\
\hline PC & & & & & & & & & & & 1 & 1 & [100] \\
\hline strawberry & & & & & & & & 1 & & 1 & & 2 & \\
\hline $\mathrm{P}$ & & & & & & & & & & 1 & & 1 & [9] \\
\hline $\mathrm{AC}$ & & & & & & & & 1 & & & & 1 & [157] \\
\hline summer squash & & & & & & & & & 1 & & & 1 & \\
\hline PC & & & & & & & & & 1 & & & 1 & [164] \\
\hline tapioca & & & & & & & & & & & 1 & 1 & \\
\hline
\end{tabular}


Table 1. Cont

\begin{tabular}{|c|c|c|c|c|c|c|c|c|c|c|c|c|c|}
\hline \multirow[t]{2}{*}{ Product/Class } & \multicolumn{11}{|c|}{ Year of Publication } & \multirow[t]{2}{*}{ \# of Papers } & \multirow[t]{2}{*}{ Reference Number } \\
\hline & 2009 & 2010 & 2011 & 2012 & 2013 & 2014 & 2015 & 2016 & 2017 & 2018 & 2019 & & \\
\hline PC & & & & & & & & & & & 1 & 1 & [101] \\
\hline tomato & & & & & & & & & 1 & 1 & 1 & 3 & \\
\hline $\mathrm{P}$ & & & & & & & & & 1 & & & 1 & {$[61]$} \\
\hline PC & & & & & & & & & & 1 & & 1 & [98] \\
\hline $\mathrm{AC}$ & & & & & & & & & & & 1 & 1 & [144] \\
\hline vegetable & & & & & & 1 & & 1 & & 2 & & 4 & \\
\hline $\mathrm{P}$ & & & & & & 1 & & & & & & 1 & {$[63]$} \\
\hline PC & & & & & & & & & & 1 & & 1 & [99] \\
\hline $\mathrm{AC}$ & & & & & & & & 1 & & 1 & & 2 & {$[105,110]$} \\
\hline watermelon & & & & & & & 1 & 1 & & & & 2 & \\
\hline PC & & & & & & & 1 & 1 & & & & 2 & {$[65,66]$} \\
\hline zucchini & & & & & 1 & & & & & & & 1 & \\
\hline \multirow[t]{2}{*}{$\mathrm{P}$} & & & & & 1 & & & & & & & 1 & [39] \\
\hline & 22 & 6 & 2 & 6 & 14 & 15 & 11 & 18 & 14 & 31 & 20 & 159 & \\
\hline
\end{tabular}




\subsection{Direct and Indirect Properties}

The Application of NIR spectroscopy within the horticultural field goes back to the late 1920s [2]. As with other food and feed applications, the traditional methods for determining the quality of fruit and vegetables are time-consuming and expensive. To overcome these disadvantages, the potential of NIR spectroscopy for monitoring the quality of fruit and vegetables has been evaluated by different research groups. Several papers have been published, dealing mainly with the determination of Brix (a measure of soluble solids content) and dry matter contents, using quantitative calibration models, and ascribable to $(\mathrm{P})$ categories. Unlike in the past, today, the determination of the main composition parameters, which is useful for describing the quality according to the product category, is carried out with portable instrumentation to be used in field and/or in process. Figure 1 shows the microNIR1700 (VIAVI Solutions, CA, USA), instrumentation owned by the Research Centre for Engineering and Agro-Food Processing-CREA-IT in Milan (Italy).

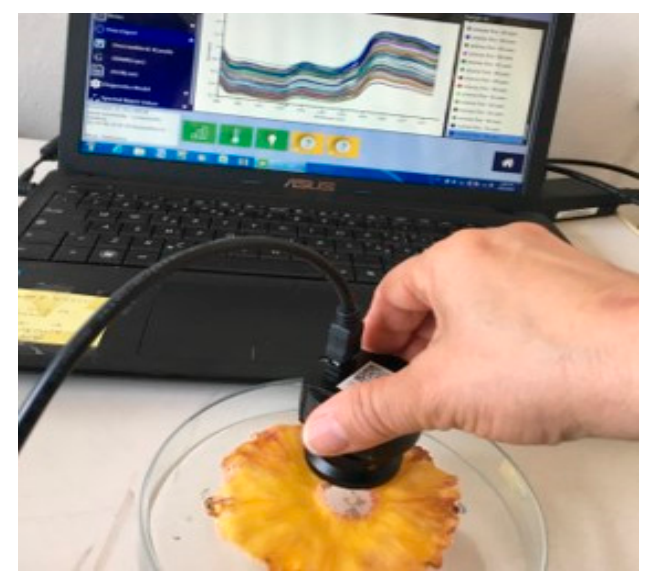

Figure 1. The microNIR1700 (VIAVI Solutions, CA, USA) at work.

The chemical and physical parameters that define intrinsic quality are often determined simultaneously thanks to the use of multicomponent calibrations. For this reason, various works report both data relating to direct index measurements (quantitative parameters) [5-39] and indirect indices ( $\mathrm{pH}$, titratable acidity, texture characteristics, and sensory parameters) [40-63]: They are reported in Table 1 with the same legend group $(\mathrm{P})[30,128,146-152]$. In order to get an idea of the predictive ability of a model, a number of statistical measures were used. These can be applied to the calibration set (the group of samples that were used to build the model parameters), the cross-validation set (samples temporarily excluded from model development but still ultimately involved in the development of the model), and the independent set (samples that have no input in the development of the model). Among the main important statistics figures, RPD (ratio of standard error of performance to standard deviation) and RER (range error ratio) cover an important role because their values are dimensionless, meaning that they can be compared on the same basis between models for different constituents/properties. In 1999, AACC (American Association of Cereal Chemists) International [166] published guidelines containing general information on NIR model development, performance evaluation, and calibration transfer to instruments of a similar brand, solely focused on useful statistics. The interest of researchers during the last decade has already moved towards the study of nutritional compounds and microcomponents, such as pigments [31], lutein [38], total phenolic content [39], carotenoids [15,65,66], nitrate [164,165], and sulfur dioxide [30].

\subsection{Process Control, Authenticity, and Classification Studies}

Within the food production and processing industry, the requirements of quality control have received much focus recently. In parallel, modern near infrared (NIR) technology offers fast and cost-effective analyses that can afford quality control in both the laboratory and factory environments. 
In this paper, the term "process" has been used in the widest sense, classifying in this group of studies in-line, at-line, and online industrial applications as well as research concerning the conservation, storage, and shelf-life of horticultural products. Often, the monitoring of a transformation process is related to the control of authenticity and final quality, so papers ascribable to PC and AC applications, shown in Table 1, were reported in this paragraph. The application of NIR spectroscopy in evaluating the internal and external quality of citrus fruit has been reported in a recent review [162], where the research progress and future prospects in this field were highlighted. The authors concluded that one of the challenges facing future applications of NIRS technology is the inherent variability in fruit and similar biological products, taking into account that the choice of NIR settings and analytical frameworks could affect both the model accuracy and robustness, and this deserves attention for future research. Just as an example, a study [65] focused on the carotenoids determination on intact watermelon using an online NIR probe was mentioned. Authors concluded that lycopene, $\beta$-carotene content, and the Brix degree of watermelon could be satisfactorily predicted using an online NIR spectrometer. Even though carotenoids and sugars are located in the flesh, the presence of rind did not seem to interfere with quantitative calibration. The possibility to monitor and analyze each single fruit could represent a step forward for valorizing nutritional characteristics of agri-food products and repositioning them on the market. Furthermore, the availability of small and compact instrumentation allowed the easy checking of fruit quality along the supply chain, from harvest, to storage, to retail distribution, in order to track the product history and to identify fruit that were not managed according to the product specification, suggesting the use of NIR spectroscopy for product traceability. Predictive models based on the NIR spectra could also be developed in order to monitor product quality along the supply chain [85]. Portable devices have been also used for on-field monitoring of the ripening degree of climacteric fruits. The possibility to estimate this feature directly on the tree, through the setup of portable devices, allowed a more precise definition of the optimum time for the fruit harvest and thus improved the final quality. A recent review [163], published in Critical Reviews in Food Science and Nutrition, gave a detailed summary about the influence of physical and biological variability, as well as the correction and compensation methods for eliminating or reducing the effects in fruit and vegetable quality nondestructive inspection using imaging and spectroscopy techniques. In fact, a great variety of physical and biological properties of agricultural products influence the optical propagation properties and interaction behaviors with incident light, thus decreasing the quality inspection accuracy.

The NIR technique associated with chemometrics (PLS algorithm) allowed us to elaborate predictive models for the conventional ripening parameters [45]. Particular mention has to be made in this paragraph to the use of hyperspectral imaging systems (HSI) and scanner cameras $[5,8,60,67,81,109,112,126,129,143,144,148]$. Hyperspectral imaging is a complex, highly multidisciplinary field that can be defined as the simultaneous acquisition of spatial images in many spectrally contiguous bands. Each pixel in the hyperspectral image contains a complete spectrum. Therefore, hyperspectral imaging is a very powerful technique for characterizing and analyzing biological and food samples. The strong driving force behind the development of hyperspectral imaging systems in food quality evaluation is the integration of spectroscopic and imaging techniques for discovering hidden information nondestructively for direct identification of different components and their spatial distribution in food samples. As a result, hyperspectral imaging represents a major technological advance in the capture of morphological and chemical information from food and food products [167]. Whether fruit or vegetables (e.g., apples, tomatoes, onions or berries), products can be quickly and reliably identified using NIR technology HSI to detect impurities such as wood, paper, plastics, stones or insects. As a result, this technology is ideally suited for usage in optical sorting systems. In contrast to conventional RGB (red-green-blue) sensor systems, differences in color and shape between product and impurity are not necessary for a successful sorting process. Identification using NIR technology is based on differences in chemical composition. Therefore, leaves, branches, stems and shells of the same color can be distinguished. Hyperspectral imaging NIR technology can also be used for semiquantitative analysis of carbohydrates and to determine water content. 
HSI technology can be integrated directly into the production process. The measurement is contact-free, e.g., installed above a conveyor belt. Such systems will be applied for (i) the analysis of quality class in the respective product, (ii) determination of the optimal degree of the maturity or (iii) early detection of bruises. The analysis result can be visualized for each location point. The results can be used for a monitoring solution or a sorting process. A spatially resolved quantitative analysis of carbohydrates as well as the determination of water content on a laboratory scale can be quickly and easily performed with the hyperspectral scanning system. The measurement is carried out contact-free without any extensive sample preparation. The analysis result of the whole sample is available within seconds either as a false color image to evaluate the homogeneity or displayed as a statistical object-related analysis result. The identification routines are customized and calibrated towards the results of the reference analytics. From the literature published in the last 10 years, the strong development of HSI and MSI applications in the food industry steadily emerges with considerably wider applications in the future. Different algorithms are available for data processing, and these systems are useful for several kinds of applications: traceability, origin, online and in-line studies, and determination of physical and chemical properties. However, the cost of instrumentation is still high, and in general, no training is available for industry operators. Figure 2 shows the spectral scanner system (DV Srl, Padova, Italy) owned by the Research Centre for Engineering and Agro-Food Processing-CREA-IT in Milan (Italy).

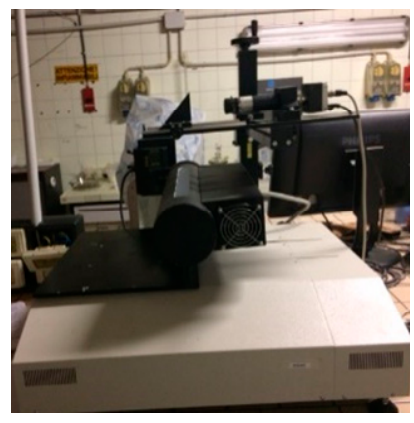

(a)

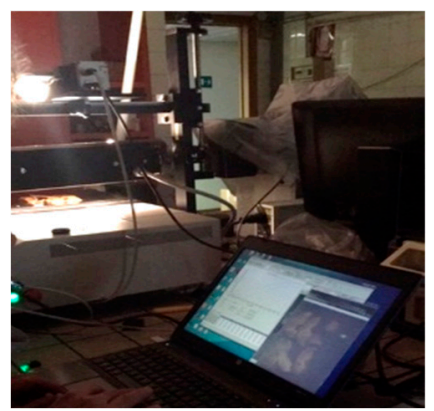

(b)

Figure 2. The DV spectral scanner (DV Srl, Padova, Italy). (a) System turned off; (b) system turned on, coupled with dedicated software.

\subsection{Advantages and Limitations of Different NIR Technologies}

When choosing a spectrometer technology, the required applications offer a good guide [168-170]. Different applications have different requirements for the spectrometer, and the preferred spectrometer technology is always application-dependent [171]. The major distinctions between spectrometer technologies (scanning grating monochromators, fixed grating detector diode array, FT-NIR) and their preferred use are reported in Table 2.

Table 2. Major distinctions between spectrometer technologies and their preferred use.

\begin{tabular}{cccc}
\hline Technology & Advantages & Limitations & Applications \\
\hline Scanning Grating & Signal/noise ratio & Measures needed to improve Wavelength accuracy & Quantitative measurements \\
& Wavelength range & Lower resolution & \\
Fixed Grating & Robustness & Signal/noise ratio & Process control [172] \\
DDA & & Sample heating & Portable instrumentation [173] \\
& & Vibration sensitive & Qualitative measurements at lab \\
FT-NIR & Wavelength accuracy & Sample heating & Authentication, identification, discrimination \\
& Resolution & &
\end{tabular}

\subsection{Aquaphotomic Approach}

Since 2007 [174], a new approach has taken hold, with a holistic view, where water and its NIR absorption bands are the leading actor. Distinct water configurations, for example, dimers, trimers, and solvation shells, are known to contribute very specifically to its NIR spectrum. These are very 
sensitive to the configuration and charges of the solvated molecules or clusters. Therefore, the NIR spectrum of the solvent (i.e., water) has been found to contain significant information about its solutes. Aquaphotomics has been developed using a deductive approach. It has two main goals: (1) to expand knowledge about the interaction between water and electromagnetic radiation, knowing all possible bands and spectral regions (water matrix coordinates, WAMACS) where water interacts with light and, thus, could be monitored; and (2) to use the water absorbance patterns (WAPS), based on WAMACS and related to water structure and functionalities in various systems, in order to deduce information about water/system peculiarities [175]. Recently, in addition to a "water vocabulary", useful chemometrics information has also been published [176] in order to correctly translate findings about water among different disciplines. Updated information on this interesting area of investigation is available online at https://www.aquaphotomics.com/.

\section{Conclusions}

The use of NIR spectroscopy in the horticultural sector is surely too large to be reported only in this review. For this reason, this paper did not have the ambition to be exhaustive and complete but to provide good suggestions in order to be able to apply NIR spectroscopy to reach personal and corporate objectives, taking into account experimental data already available and updated. Often, for scientists working in the agricultural sector, it may be difficult to consult articles published in specialized journals of other research fields; thus, the main objective of this paper was to make a large table coupled with the full list of references available, useful for a personal check of a single scientist or a team of scientists, who could then select, on the basis of product, application, year of publication, only the studies strictly related to their research area and easily uncover papers of interest. This collection of literature data showed that most of the research was developed on fruit, using portable and/or online instrumentation for the evaluation of total quality, the determination of macroconstituents and nutritional markers, as well as the presence of defects. The last decade was also characterized by a great improvement of mathematic algorithms able to solve problems related to 'apparent differences' among samples and sets that could increase the risks of misunderstanding the significance of analyzed and processed data. Near infrared technologies offer fast solutions for organic compound discrimination and quantification. With the instrumental market in constant growth and development, cheaper and yet more accurate instruments will probably offer opportunities to explore new applications and fields of work.

Funding: This research received no external funding.

Acknowledgments: Authors would thank Guest Editors Anna Rizzolo and Maristella Vanoli for this invitation.

Conflicts of Interest: The authors declare no conflict of interest.

\section{References}

1. Slaughter, D.C.; Abbott, J.A. Analysis of fruits and vegetables. In Near-Infrared Spectroscopy in Agriculture, 1st ed.; Al-Amoodi, L., Roberts, C.A., Workman, J., Jr., Reeves, J.B., III, Eds.; ASA, CSSA, SSSA Publishers: Madison, WI, USA, 2004; pp. 378-398.

2. Saranwong, S.; Kawano, S. Fruits and vegetables. In Near Infrared Spectroscopy in Food Science and Technology; Osaki, Y., McClure, W.F., Christy, A., Eds.; John Wiley \& Sons, Inc.: Hoboken, NJ, USA, 2007; pp. $219-245$.

3. Nicolai, B.M.; Beullens, K.; Bobelyn, E.; Saeys, W.; Theoron, K.I.; Lammertyn, J. Nondestructive measurement of fruit and vegetable quality by means of NIR spectroscopy: A review. Postharvest Biol. Technol. 2007, 46, 99-118. [CrossRef]

4. Kawano, S. Past, present and future near infrared spectroscopy applications for fruit and vegetables. NIRNews 2016, 27, 7-9. [CrossRef]

5. Malegori, C.; Gowen, A.; Marquez, E.; Pimentel, M.F.; Tonetto de Freitas, S.; Pasquini, C.; Casiraghi, E. Selection of NIR wavelengths from hyperspectral imaging data for quality evaluation of Acerola fruit. In Proceedings of the 17th International Conference on Near Infrared Spectroscopy, Foz do Iguassu, Brazil, 18-23 October 2015; pp. 65-69. 
6. Tamburini, E.; Mamolini, E.; De Bastiani, M.; Marchetti, M.G. Quantificazione di fusarium proliferatum in bulbilli di aglio interi. In Proceedings of the Atti del 7th Simposio Italiano di Spettroscopia NIR, Lodi, Italy, 12-14 October 2016; pp. 105-109.

7. Wedding, B.B.; Wright, C.; Grauf, S.; White, R.D.; Tilseaand, B.; Gadek, P. Prediction of hass avocado maturity via FT-NIRS. In Proceedings of the 14th ICNIRS Conference, Bangkok, Thailand, 7-12 November 2009; pp. 261-264.

8. Pu, Y.Y.; Sun, D.-W.; Riccioli, C.; Buccheri, M.; Grassi, M.; Cattaneo, T.M.P.; Gowen, A. Calibration Transfer from Micro NIR Spectrometer to Hyperspectral Imaging: A Case Study on Predicting Soluble Solids Content of Bananito Fruit (Musa acuminata). Food Anal. Methods 2018, 11, 1021-1033. [CrossRef]

9. Chen, H.; Liu, Z.; Cai, K.; Xu, L.; Chen, A. Grid search parametric optimization for FT-NIR quantitative analysis of solid soluble content in strawberry samples. Vib. Spectrosc. 2018, 94, 7-15. [CrossRef]

10. Kaur, H.; Künnemeyer, R.; McGlone, A. Comparison of hand-held near infrared spectrophotometers for fruit dry matter assessment. J. Near Infrared Spectrosc. 2017, 25, 267-277. [CrossRef]

11. Gabioud, S.R.; Kamm, B.; Baumgartner, D.; Bozzi, A.N. Comparison of two Vis-NIR instruments based on reflectance or interactance mode for fruit quality measurements. In Proceedings of the 15th International Conference on Near Infrared Spectroscopy, Cape Town, South Africa, 13-20 May 2011; pp. 474-477.

12. Tian, X.; Wang, Q.; Li, J.; Peng, F.; Huang, W. Non-destructive prediction of soluble solids content of pear based on fruit surface feature classification and multivariate regression analysis. Infrared Phys. Technol. 2018, 92, 336-344. [CrossRef]

13. Kurata, Y.; Tshuchikawa, S. Time-of-flight near infrared spectroscopy for detecting sugar and acid contents in thick-peel fruit. In Proceedings of the 14th ICNIRS Conference, Bangkok, Thailand, 7-12 November 2009; pp. 209-212.

14. Sirisomboon, P. NIR Spectroscopy for quality evaluation of fruits and vegetables. Spectrochimca Acta Part A Mol. Biomol. Spectrosc. 2018, 214, 366-371. [CrossRef]

15. De Oliveira, G.A.; de Castilhos, F.; Renard, C.M.G.; Bureau, S. Comparison of NIR and MIR spectroscopic methods for determination of individual sugars, organic acids and carotenoids in passion fruit. Food Res. Int. 2014, 60, 154-162. [CrossRef]

16. Torres Mariani, N.C.; de Almeida Teixeira, G.H.; de Lima, K.M.G.; Morgenstern, T.B.; Nardini, V.; Cunha Júnior, L.C. NIRS and iSPA-PLS for predicting total anthocyanin content in jaboticaba fruit. Food Chem. 2015, 174, 643-648. [CrossRef]

17. Masithoh, R.E.; Saranwong, S.; Kawano, S. Nondestructive measurement of brix value and total acidity in satsuma mandarin by a hand-held near infrared instrument. In Proceedings of the 14th ICNIRS Conference, Bangkok, Thailand, 7-12 November 2009; pp. 241-244.

18. Rungpichayapichet, P.; Mahayothee, B.; Naglea, M.; Müller, J. Application of near-infrared spectroscopy to determine the $\beta$-carotene content of mango. In Proceedings of the NIR 2013-Picking up Good Vibrations, 16th International Conference on Near Infrared Spectroscopy, La Grande-Motte, France, 2-7 June 2013; pp. 161-166.

19. Theanjumpol, P.; Sardsud, V.; Self, G. Determination of characteristic absorption bands for carbohydrates and organic acids in mango purée. In Proceedings of the 14th ICNIRS Conference, Bangkok, Thailand, 7-12 November 2009; pp. 291-294.

20. Felde, T.; Alamu, O.E.; Porras, E.; Maroya, N.; Maziya-Dixon, B. Screening for pro-vitamin A components in Cassava (Manihot esculenta) using NIR to support bio-fortification. In Proceedings of the NIR 2013-Picking up Good Vibrations, 16th International Conference on Near Infrared Spectroscopy, La Grande-Motte, France, 2-7 June 2013; pp. 182-186.

21. Yan, H.; Lu, D.L.; Chen, B.; Hansen, W.G. Development of a hand-held near infrared system based on an android OS and MicroNIR, and its application in measuring soluble solids content in fuji apples. Nir News 2014, 25, 16-19. [CrossRef]

22. Guan, X.; Liu, J.; Huang, K.; Kuang, J.; Liu, D. Evaluation of moisture content in processed apple chips using NIRS and wavelength selection techniques. Infrared Phys. Technol. 2019, 98, 305-310. [CrossRef]

23. Qi, S.; Oshita, S.; Makino, Y.; Han, D. Influence of sampling component on determination of soluble solids content of fuji apple using near-infrared spectroscopy. Appl. Spectrosc. 2017, 71, 856-865. [CrossRef] [PubMed] 
24. Fan, S.; Li, J.; Xia, Y.; Tian, X.; Guo, Z.; Huang, W. Long-term evaluation of soluble solids content of apples with biological variability by using near-infrared spectroscopy and calibration transfer method. Postharvest Biol. Technol. 2019, 151, 79-87. [CrossRef]

25. Zhang, Y.; Nock, Y.F.; Al Shoffe, Y.; Watkins, C.B. Non-destructive prediction of soluble solids and dry matter contents in eight apple cultivars using near-infrared spectroscopy. Postharvest Biol. Technol. 2019, 151, 111-118. [CrossRef]

26. Luo, X.; Ye, Z.; Xu, H.; Zhang, D.; Bai, S.; Ying, Y. Robustness improvement of NIR-based determination of soluble solids in apple fruit by local calibration. Postharvest Biol. Technol. 2018, 139, 82-90. [CrossRef]

27. Schmutzler, M.; Huck, C.W. Simultaneous detection of total antioxidant capacity and total soluble solids content by Fourier transform near-infrared (FT-NIR) spectroscopy: A quick and sensitive method for on-site analyses of apples. Food Control 2016, 66, 27-37. [CrossRef]

28. Bai, W.; Yoshimura, N.; Takayanagi, M. Quantitative analysis of ingredients of blueberry fruits by near infrared spectroscopy. J. Near Infrared Spectrosc. 2014, 22, 357-365. [CrossRef]

29. Kasemsumran, S.; Thanapase, W.; Punsuvon, V.; Ozaki, Y. A feasibility study on non-destructive determination of oil content in palm fruits by visible-Near infrared spectroscopy. J. Near Infrared Spectrosc. 2012, 20, 687-694. [CrossRef]

30. Rongtong, B.; Suwonsichon, T.; Ritthiruangdej, P.; Kasemsumran, S. Determination of sulfur dioxide content in osmotically dehydrated papaya and its classification by near infrared spectroscopy. J. Near Infrared Spectrosc. 2018, 26, 359-368. [CrossRef]

31. Zou, X.B.; Li, Y.X.; Zhao, J.W.; Mao, H.P.; Huang, X.Y.; Shi, J.Y.; Yin, X.P. Determination of soluble proteins and photosynthetic pigments of cherry tomato leaves using near-infrared spectroscopy. In Proceedings of the 14th ICNIRS Conference, Bangkok, Thailand, 7-12 November 2009; pp. 47-51.

32. Liu, J.; Han, J.; Chen, X.; Shi, L.; Zhang, L. Nondestructive detection of rape leaf chlorophyll level based on Vis-NIR spectroscopy. Spectrochim. Acta Part A Mol. Biomol. Spectrosc. 2019, 35, 433-438. [CrossRef]

33. Yoshida, M.; Soga, A.; Asada, S. Quality evaluation of 'Shonan Gold' by near infrared spectroscopy. In Proceedings of the 14th ICNIRS Conference, Bangkok, Thailand, 7-12 November 2009; pp. 281-284.

34. Cagnasso, E.; Torchio, F.; Rolle, L.; Ferrari, G.; Campolongo, G.; Gerbi, V. Applicazione Della Spettrometria FT-NIR All'Analisi Della Maturità Fenolica e Tecnologica dell'uva. In Proceedings of the Atti IV Simposio Italiano di Spettroscopia NIR, Sestri Levante, Italy, 13-14 May 2010.

35. Cozzolino, D.; Cynkar, W.U.; Dambergs, R.G.; Shah, N.; Mercurio, M.; Smith, P. Grape tannin measurement by near infrared spectroscopy. In Proceedings of the 14th ICNIRS Conference, Bangkok, Thailand, 7-12 November 2009; pp. 297-298.

36. Cynkar, W.U.; Grayston, G.; Cozzolino, D.; Dambergs, R.G.; Shah, N.; Smith, P. Prediction of grape compositional parameters using a Fourier transform near infrared instrument. In Proceedings of the 14th ICNIRS Conference, Bangkok, Thailand, 7-12 November 2009; pp. 295-296.

37. Piazzolla, F.; Amodio, M.L.; Colelli, G. Applicazione di tecniche non-distruttive sulla qualità di uva da tavola. In Proceedings of the Atti 5 Simposio Italiano di Spettroscopia NIR, Legnaro, Italy, 26-28 September 2012; p. 137.

38. Martínez-Valdivieso, D.; Blanco-Díaz, M.T.; Gómeza, P.; Moreno-Rojasb, J.M.; Font, R.; Del Río-Celestino, M. Prediction by infrared reflectance spectroscopy of the lutein content in summer squash fruits. In Proceedings of the NIR 2013-Picking up Good Vibrations, 16th International Conference on Near Infrared Spectroscopy, La Grande-Motte, France, 2-7 June 2013; pp. 156-160.

39. Blanco-Díaz, M.T.; Del Río-Celestino, M.; Martínez-Valdivieso, D.; Moreno, J.M.; Peña-Rodriguez, F.; Font, R. Use of near-infrared reflectance spectroscopy for predicting total phenolic content in zucchini fruits. In Proceedings of the NIR 2013-Picking up Good Vibrations, 16th International Conference on Near Infrared Spectroscopy, La Grande-Motte, France, 2-7 June 2013; pp. 142-144.

40. Ngowsuwan, K.; Thanapatay, D.; Kasemsumran, S. Performance improvement of temperature compensation in near infrared analysis of orange sweetness by applying direct standardization. J. Near Infrared Spectrosc. 2018, 26, 369-378. [CrossRef]

41. Malegori, C.; Nascimento, E.J.M.; de Freitas, S.T.; Pimentel, M.F.; Pasquini, C.; Casiraghi, E. Comparing the analytical performances of Micro-NIR and FT-NIR spectrometers in the evaluation of acerola fruit quality, using PLS and SVM regression algorithms. Talanta 2017, 165, 112-116. [CrossRef] [PubMed] 
42. Firtha, F.; Gillay, Z.; Vozáry, E.; Kasza, T.; Lambert-Meretei, A.; Felföldi, J. Multi-spectral assessment of ingredients and physical properties of apricot. In Proceedings of the 14th ICNIRS Conference, Bangkok, Thailand, 7-12 November 2009; pp. 245-250.

43. Wang, T.; Chen, J.; Fan, Y.; Qiu, Z. SeeFruits: Design and evaluation of a cloud-based ultra-portable NIRS system for sweet cherry quality detection. Comput. Electron. Agric. 2018, 152, 302-313. [CrossRef]

44. Tomer, N.; McGlone, A.; Künnemeyer, R. Validated multi-wavelength simulations of light transport in healthy onion. Comput. Electron. Agric. 2018, 146, 22-30. [CrossRef]

45. Bertone, E.; Calderara, M.; Giraudo, A.; Venturello, A.; Geobaldo, F. Applicazione in campo di strumentazione portatile FT-NIR e UV-VIS per la determinazione del grado di maturazione di frutti climaterici. In Proceedings of the Atti del 6th Simposio Italiano di Spettroscopia NIR, Lodi, Italy, 28-30 May 2014; p. 63.

46. Subedi, P.P.; Walsh, K.B.; Hopkins, D.W. Assessment of titratable acidity in fruit using short wave near infrared spectroscopy part B: Intact fruit studies. J. Near Infrared Spectrosc. 2012, 20, 449-457. [CrossRef]

47. De Oliveira, A.G.; Bureau, S.; Geneviève, C.M.; Renard, C.; Pereira-Netto, A.B.; de Castilhos, F. Comparison of NIRS approach for prediction of internal quality traits in three fruit species. Food Chem. 2014, 143, $223-230$. [CrossRef] [PubMed]

48. Arendse, E.; Fawole, O.A.; Magwaza, L.S.; Nieuwoudt, H.; Opara, U.L. Fourier transform near infrared diffuse reflectance spectroscopy and two spectral acquisition modes for evaluation of external and internal quality of intact pomegranate fruit. Postharvest Biol. Technol. 2018, 138, 91-98. [CrossRef]

49. Acharya, U.K.; Walsh, K.B.; Subedi, P.P. Robustness of partial least-squares models to change in sample temperature: II. Application to fruit attributes. J. Near Infrared Spectrosc. 2014, 22, 287-295. [CrossRef]

50. Oliveira-Foladora, G.; Oliveira, B.M.; Andrade, E.F.; ClaireRenard, C.M.G.; Bureau, S.; de Castilhos, F. Quality traits prediction of the passion fruit pulp using NIR and MIR spectroscopy. LWT 2018, 95, 172-178. [CrossRef]

51. Alamar, P.D.; Caramês, E.T.S.; Poppi, R.J.; Pallone, J.A.L. Quality evaluation of frozen guava and yellow passion fruit pulps by NIR spectroscopy and chemometrics. Food Res. Int. 2016, 85, 209-214. [CrossRef]

52. McGlone, V.A.; Seelye, R.; Popowski, E.; Lowe, R.; Gea, L. Kiwifruit maturity screening by NIR; dealing with genotype variation. In Proceedings of the 14th ICNIRS Conference, Bangkok, Thailand, 7-12 November 2009; pp. 251-254.

53. Terdwongworakul, A.; Laosubchareon, P.; Kasemsumranban, S.; Thanapase, W. Use of peel spectral information to improve titratable acidity prediction in intact tangerine by near infrared spectroscopy in long wavelength region. In Proceedings of the 14th ICNIRS Conference, Bangkok, Thailand, 7-12 November 2009; pp. 229-235.

54. Neto, J.S.; Cunha Júnior, L.; Teixeira, G. Determination of 'Palmer' mango maturity indexes by NIR spectroscopy. Postharvest Biol. Technol. 2017, 130, 75-80. [CrossRef]

55. Dos Santos Neto, J.P.; de Assis, M.W.D.; Parkutz Casagrande, I.; Cunha Júnior, L.C.; de Almeida Teixeira, G.H. Determination of 'Palmer' mango maturity indices using portable near infrared (VIS-NIR) spectrometer. Postharvest Biol. Technol. 2017, 130, 75-80. [CrossRef]

56. Nordey, T.; Joas, J.; Davrieux, F.; Chillet, M.; Léchaudel, M. Robust NIRS models for non-destructive prediction of mango internal quality. Sci. Hortic. 2017, 216, 51-57. [CrossRef]

57. Rungpichayapichet, P.; Mahayothee, B.; Nagle, M.; Khuwijitjaru, P.; Müller, J. Robust NIRS models for non-destructive prediction of postharvest fruit ripeness and quality in mango. Postharvest Biol. Technol. 2016, 111, 31-40. [CrossRef]

58. Kumar, S.; McGlone, A.; Whitworth, C.; Volz, R. Postharvest performance of apple phenotypes predicted by near-infrared (NIR) spectral analysis. Postharvest Biol. Technol. 2015, 100, 16-22. [CrossRef]

59. Abasi, S.; Minaei, S.; Jamshidi, B.; Fathi, D.; Khoshtaghaza, M.H. Rapid measurement of apple quality parameters using wavelet de-noising transform with Vis/NIR analysis. Sci. Hortic. 2019, 252, 7-13. [CrossRef]

60. Maestresalas, A.L.; Keresztes, J.C.; Arazuri, S.; Jarén, C.; Saeys, W. Recent applications of near infrared hyperspectral imaging for quality inspection in the potato sector. Nir News 2016, 27, 11-14. [CrossRef]

61. Sánchez, M.T.; Torres, I.; De la Haba, M.J.; Garrido-Varo, A.; Pérez-Marín, D. Evaluation of NIRS for the prediction of physical and sensorial quality parameters in intact RAF tomato. In Proceedings of the 18th International Conference on Near Infrared spectroscopy-NIR Spectroscopy at work in Industry (Program Book), Copenhagen, Denmark, 11-15 June 2017; p. 41.

62. Sánchez, M.T.; Entrenas, J.A.; Torres, I.; Vega, M.; Pérez-Marín, D. Monitoring texture and other quality parameters in spinach plants using NIR spectroscopy. Comput. Electron. Agric. 2018, 155, 446-452. [CrossRef] 
63. Civelli, R.; Beghi, R.; Giovenzana, V.; Buratti, S.; Guidetti, R. Analisi della freschezza di valerianella locusta laterr. di IV gamma mediante spettroscopia VIS/NIR. In Proceedings of the Atti del 6th Simposio Italiano di Spettroscopia NIR, Lodi, Italy, 28-30 May 2014; pp. 152-157.

64. Malegori, C.; Marques, E.J.N.; Pimentel, M.F.; Tonetto de Freitas, S.; de França Souza, F.; Pasquini, C.; Casiraghi, E. Utilizzo del micro-NIR per la valutazione della maturazione dell'acerola. In Proceedings of the Atti del 7th Simposio Italiano di Spettroscopia NIR, Lodi, Italy, 12-14 October 2016; p. 64.

65. Tamburini, E.; Ferrari, G.; Pedrini, P.; Donegà, V.; Malavasi, M.; Marchetti, M.G. Non-destructive quantification of carotenoids in intact watermelon (Citrullus lanatus) using on-line near infrared spectroscopy. In Proceedings of the 17th International Conference on Near Infrared Spectroscopy, Foz do Iguassu, Brazil, 18-23 October 2015; pp. 32-36.

66. Tamburini, E.; Ferrari, G.; Pedrini, P.; Donegà, V.; Malavasi, M.; Marchetti, M.G. Quantificazione non distruttiva del contenuto di carotenoidi in cocomeri interi (Citrullus lanatus) attraverso la tecnica NIR-on line 110. In Proceedings of the Atti del 7th Simposio Italiano di Spettroscopia NIR, Lodi, Italy, 12-14 October 2016; pp. 110-114.

67. Ncama, K.; Magwaza, L.S.; Echeverrı', C.A.P.; Nieuwoud, H.H.; Tesfay, S.Z.; Mditshwa, A. On-tree indexing of 'Hass' avocado fruit by non-destructive assessment of pulp dry matter and oil content. Biosyst. Eng. 2018, 174, 41-49. [CrossRef]

68. Pu, Y.Y.; Cattaneo, T.M.P.; Buccheri, M.; Grassi, M.; Gowen, A. Modelli previsionali per la valutazione dello stadio di maturazione di bananito mediante hyperspectral imaging. In Proceedings of the Atti del 7th Simposio Italiano di Spettroscopia NIR, Lodi, Italy, 12-14 October 2016; p. 145.

69. Bureau, S.; Bertrand, D.; Jaillais, B.; Reling, P.; Gouble, B.; Renard, C.M.G.C.; Dekdouk, B.; Marsh, L.A.; O'Toole, M.D.; Armitage, D.W.; et al. Fruitgrading: Development of a fruit sorting technology based on internal quality parameters. In Proceedings of the NIR 2013-Picking up Good Vibrations, 16th International Conference on Near Infrared Spectroscopy, La Grande-Motte, France, 2-7 June 2013; pp. 145-148.

70. Nordey, T.; Davrieux, F.; Léchaudel, M. Predictions of fruit shelf life and quality after ripening: Are quality traits measured at harvest reliable indicators? Postharvest Biol. Technol. 2019, 153, 52-60. [CrossRef]

71. Acharya, U.K.; Walsh, K.B.; Hayes, C.; Subedi, P.P. Spectrophotometer ageing and prediction of fruit attributes. J. Near Infrared Spectrosc. 2016, 24, 337-344. [CrossRef]

72. Walsh, K.B.; Subedi, P.P. Starch and sugar-The assessment of maturation and ripening of fruit by shortwave near infrared spectroscopy. In Proceedings of the 14th ICNIRS Conference, Bangkok, Thailand, 7-12 November 2009; pp. 225-228.

73. Mcglone, A.; Wohlers, M. The introduction of commercial NIR fruit grading in the New Zealand kiwifruit industry: Performance analysis. In Proceedings of the 18th International Conference on Near Infrared spectroscopy-NIR Spectroscopy at work in Industry (Program Book) Bella Center, Copenhagen, Denmark, 11-15 June 2017; p. 38.

74. De la Haba, M.J.; Garrido-Varo, A.; Sanchez, M.T.; Guerrero Ginel, J.E.; Pérez-Marin, D. On-tree monitoring of quality evolution in citrus by using a mems-based NIR spectro-photometer. In Proceedings of the NIR 2013-Picking up Good Vibrations, 16th International Conference on Near Infrared Spectroscopy, La Grande-Motte, France, 2-7 June 2013; pp. 149-152.

75. Cheng, W.; Sørensen, K.M.; Mongi, R.J.; Ndabikunze, B.K.; Chove, B.E.; Sun, D.W.; Engelsen, S.B. A comparative study of mango solar drying methods by visible and near-infrared spectroscopy coupled with ANOVA-simultaneous component analysis (ASCA). LWT 2019, 112, 108214. [CrossRef]

76. Nagle, M.; Mahayothee, B.; Rungpichayapichet, P.; Janjai, S.; Müller, J. Effect of irrigation on near-infrared (NIR) based prediction of mango maturity. Sci. Hortic. 2010, 125, 771-774. [CrossRef]

77. Rungpichayapichet, P.; Mahayothee, B. Influence of harvesting period on mango quality as determined by near infrared spectroscopy. In Proceedings of the 14th ICNIRS Conference, Bangkok, Thailand, 7-12 November 2009; pp. 277-279.

78. Pornprasit, R.; Theanjumpol, P.; Pattana, S.; Klongpanichban, W.; Natwichai, J. Prototype of automatic line sorting of mango. In Proceedings of the 14th ICNIRS Conference, Bangkok, Thailand, 7-16 November 2009; pp. 285-289. 
79. Vanoli, M.; Rizzolo, A.; Grassi, M.; Meirelles de Azevedo Pimentel, R.; Eccher Zerbini, P.; Spinelli, L.; Torricelli, A. Valutazione non distruttiva dell'età biologica di mango brasiliani mediante spettroscopia VIS/NIR risolta nel tempo. In Proceedings of the Atti 5 Simposio Italiano di Spettroscopia NIR, Legnaro, Italy, 26-28 September 2012; pp. 113-118.

80. Sinelli, N.; Giovanelli, G.; Fongaro, L.; Beghi, R.; Casiraghi, E. Applicazione della spettroscopia NIR per ottimizzare la gestione delle mele in post-raccolta. In Proceedings of the Atti IV Simposio Italiano di Spettroscopia NIR, Sestri Levante, Italy, 13-14 May 2010; pp. 241-242.

81. Li, J.; Luo, W.; Wang, Z.; Fan, S. Early detection of decay on apples using hyperspectral reflectance imaging combining both principal component analysis and improved watershed segmentation method. Postharvest Biol. Technol. 2019, 149, 235-246. [CrossRef]

82. Schmilovitch, Z.; Ignat, T.; Nyasordzi, J.; Ostrovsky, V.; Egozia, H.; Hoffman, A.; Friedman, H.; Wekslerb, A.; Rotb, I.; Lurie, S. Forecast of apple internal quality indices during storage by spectroscopy. In Proceedings of NIR 2013—Picking Up Good Vibrations; Bellon-Maurel, V., Williams, P., Downey, G., Eds.; IRSTEA: Montpellier, France, 2013; pp. 171-176.

83. Sanchez, M.T.; Garrido-Varo, A.; De la Haba, M.J.; Fernandez-Novales, J.; Guerrero-Ginel, J.E.; Perez-Marin, D. In situ monitoring of fruit ripening during posthaverst storage using a miniature handheld NIR sensor. In Proceedings of the NIR 2013-Picking up Good Vibrations, 16th International Conference on Near Infrared Spectroscopy, La Grande-Motte, France, 2-7 June 2013; pp. 167-170.

84. McCormick, R.; Biegert, K. Monitoring the growth and maturation of apple fruit on the tree with handheld Vis/NIR devices. Nir News 2018, 30, 12-15. [CrossRef]

85. Buccheri, M.; Grassi, M.; Lovati, F.; Petriccione, M.; Rega, P.; Lo Scalzo, R.; Cattaneo, T.M.P. Near infrared spectroscopy in the supply chain monitoring of Annurca apple. J. Near Infrared Spectrosc. 2018, 27, 86-92. [CrossRef]

86. Giovanelli, G.; Sinelli, N.; Beghi, R.; Guidetti, R.; Casiraghi, E. NIR spectroscopy for the optimization of postharvest apple management. Postharvest Biol. Technol. 2014, 87, 13-20. [CrossRef]

87. Buccheri, M.; Grassi, M.; Lovati, F.; Petriccione, M.; Rega, P.; Lo Scalzo, R.; Cattaneo, T.M.P. NIR spectroscopy in the supply chain monitoring of Annurca apple (IGP). In Proceedings of the Atti del 8th Simposio Italiano di Spettroscopia NIR, Lodi, Italy, 30-31 May 2018; p. 84.

88. Khatiwada, B.; Subedi, P.; Hayes, C.; Walsh, K.; Loeffen, M. Sorting for internal flesh browning in apple using visible-shortwave near infrared spectroscopy. In Proceedings of the 17th International Conference on Near Infrared Spectroscopy, Foz do Iguassu, Brazil, 18-23 October 2015; pp. 61-64.

89. Buccheri, M.; Grassi, M.; Lovati, F.; Pietriccione, M.; Rega, P.; Lo Scalzo, R.; Cattaneo, T.M.P. The Aquaphotomics approach to discriminate apples stored in air or in controlled atmosphere. In Proceedings of the Atti del 8th Simposio Italiano di Spettroscopia NIR, Genova, Italy, 30-31 May 2018; p. 86.

90. Eisenstecken, D.; Stürz, B.; Robatscher, P.; Lozano, L.; Zanella, A.; Oberhuber, M. The potential of near infrared spectroscopy (NIRS) to trace apple origin: Study on different cultivars and orchard elevations. Postharvest Biol. Technol. 2019, 147, 123-131. [CrossRef]

91. Barzaghi, S.; Cremonesi, K. Use of near infrared spectroscopy to discriminate pink lady ${ }^{\circledR}$ and golden delicious apples after different storage protocols. In Proceedings of the NIR 2013-Picking up Good Vibrations, 16th International Conference on Near Infrared Spectroscopy, La Grande-Motte, France, 2-7 June 2013; pp. 772-777.

92. Barzaghi, S.; Cremonesi, K.; Pani, P. Utilizzo della spettroscopia NIR per lo studio del processo di essiccamento di mele osmodisidratate. In Proceedings of the Atti IV Simposio Italiano di Spettroscopia NIR, Sestri Levante, Italy, 13-14 May 2010; pp. 200-205.

93. Carvalho, L.C.; Leite, M.L.; Morais, C.L.M.; Lima, K.M.G.; Teixeira, G.H.A. Non-destructive assessment of the oxidative stability of intact macadamia nuts during the drying process by near-infrared spectroscopy. LWT 2019, 103, 101-107. [CrossRef]

94. Casiraghi, E.; Grassi, S.; Giovenzana, V.; Guidetti, R.; Alamprese, C. Application of FT-NIR spectroscopy to assess the ripening stage of olives. In Proceedings of the Atti del 8th Simposio Italiano di Spettroscopia NIR, Genova, Italy, 30-31 May 2018; p. 80.

95. Allouche, Y.; López, E.F.; Maza, G.B.; Márquez, A.J. Near infrared spectroscopy and artificial neural network to characterise olive fruit and oil online for process optimisation. J. Near Infrared Spectrosc. 2015, 23, 111-121. [CrossRef] 
96. Stella, E.; Moscetti, R.; Haff, R.P.; Monarca, D.; Cecchini, M.; Contini, M.; Massantini, R. Review: Recent advances in the use of non-destructive near infrared spectroscopy for intact olive fruits. J. Near Infrared Spectrosc. 2015, 23, 197-208. [CrossRef]

97. Cattaneo, T.M.P.; Grassi, M.; Vanoli, M.; Barzaghi, S.; Rizzolo, A. Strumentazione NIR portatile nella valutazione della shelf life di prodotti caseari, ortofrutticoli e di norcineria. In Proceedings of the Atti del 6th Simposio Italiano di Spettroscopia NIR, Modena, Italy, 28-30 May 2014; pp. 118-123.

98. Giovenzana, V.; Tugnolo, A.; Guidetti, R.; Beghi, R. Potential effectiveness of visible and near infrared spectroscopy coupled with wavelengths selection for real time control of the fresh fruit and vegetable quality in large-scale mass distribution channel: The case study of tomatoes. In Proceedings of the Atti del 8th Simposio Italiano di Spettroscopia NIR, Genova, Italy, 30-31 May 2018; p. 88.

99. Chaudhry Muhammad, M.A.; Amodio, M.L.; Babellahi, F.; Amigo Rubio, J.M.; Colelli, G. Uso di immagini iperspettrali e tecniche multivariate per la predizione della shelf-life di foglie di rucola minimamente processate. In Proceedings of the Atti del 8th Simposio Italiano di Spettroscopia NIR, Genova, Italy, 30-31 May 2018; p. 21.

100. Pérez-Marín, D.; Torres, I.; Entrenas, J.A.; Vega, M.; Sánchez, M.T. Pre-harvest screening on-vine of spinach quality and safety using NIRS technology. Spectrochim. Acta Part A Mol. Biomol. Spectrosc. 2019, 207, $242-250$. [CrossRef] [PubMed]

101. Phetpan, K.; Udompetaikul, V.; Sirisomboon, P. In-line near infrared spectroscopy for the prediction of moisture content in the tapioca starch drying process. Powder Technol. 2019, 345, 608-615. [CrossRef]

102. Xiaoa, H.; Lia, A.; Lia, M.; Suna, Y.; Tua, K.; Wangb, S.; Pana, L. Quality assessment and discrimination of intact white and red grapes from Vitis vinifera L. at five ripening stages by visible and near-infrared spectroscopy. Sci. Hortic. 2018, 233, 99-107. [CrossRef]

103. Beghi, R.; Giovenzana, V.; Civelli, R.; Oberti, R.; Guidetti, R. Sperimentazione di un sistema ottico semplificato per la valutazione rapida della maturazione di uva bianca da vino 57. In Proceedings of the Atti del 7th Simposio Italiano di Spettroscopia NIR, Milano, Italy, 12-14 October 2016; pp. 57-62.

104. Malegori, C.; Grassi, S.; Marquez, E.; Tonetto de Freitas, S.; Casiraghi, E. Mappatura della vitamina c in immagini hs-NIR di acerola mediante CLS. In Proceedings of the Atti del 7th Simposio Italiano di Spettroscopia NIR, Milano, Italy, 12-14 October 2016; p. 71.

105. Kang, Y.S.; Ryu, C.S.; Jun, S.R.; Jang, S.H.; Park, J.W.; Song, H.Y.; Sarkar, T.K.; Kim, S.H.; Lee, W.S. Distinguishing between closely related species of allium and of brassicaceae by narrowband hyperspectral imagery. Biosyst. Eng. 2018, 176, 103-113. [CrossRef]

106. Windham, W.; Poole, G.; Park, B.; Heitschmidt, G.; Gottwald, T.; Lawrence, K.C. Near-infrared spectroscopy for discrimination of huanglongbing-infected citrus leaves from uninfected leaves. In Proceedings of the 14th ICNIRS Conference, Bangkok, Thailand, 7-12 November 2009; pp. 235-239.

107. Richter, B.; Rurik, M.; Gurk, S.; Kohlbacher, O.; Fischer, M. Food monitoring: Screening of the geographical origin of white asparagus using FT-NIR and machine learning. Food Control 2019, 104, 318-325. [CrossRef]

108. Wedding, B.; Wright, C.; Grauf, S.; White, R.; Gadek, P. Impact assessment and prediction of rot susceptibility of Hass avocado fruit using FT-NIRspectroscopy142. In Proceedings of the 15th International Conference on Near Infrared Spectroscopy, Cape Town, South Africa, 13-20 May 2011; pp. 398-401.

109. Amodio, M.L.; Berardi, A.; Ricci, I.; Colelli, G. Utilizzo di imaging iperspettrale per la discriminazione varietale e di raccolto di carciofi. In Proceedings of the Atti del 7th Simposio Italiano di Spettroscopia NIR, Milano, Italy, 12-14 October 2016; p. 143.

110. Giovenzana, V.; Beghi, R.; Civelli, R.; Guidetti, R. Application of near infrared spectroscopy and development of simplified optical devices for the fresh-cut fruit and vegetable sector. Nir News 2016, 27, 4-6. [CrossRef]

111. Müller, C.; Leontin, D.; Cintu Pînzaru, S. Detection of Thiabendazole Applied to Organic Fruit by Near Infrared Surface-Enhanced Raman. Available online: www.spectroscopyspectroscopyeurope.com (accessed on 1 August 2013).

112. Wu, Q.; Xie, L.; Xu, X. Determination of toxigenic fungi and aflatoxins in nuts and dried fruits using imaging and spectroscopic techniques. Food Chem. 2018, 252, 228-242. [CrossRef] [PubMed]

113. Nturambirwe, J.F.I.; Nieuwoudt, H.H.; Perold, W.J.; Opara, U.L. Non-destructive measurement of internal quality of apple fruit by a contactless NIR spectrometer with genetic algorithm model optimization. Sci. Afr. 2019, 3, e00051. [CrossRef] 
114. Walsh, K. Classification of citrus fruit with ensemble techniques. In Proceedings of the 18th International Conference on Near Infrared spectroscopy-NIR Spectroscopy at work in Industry (Program Book), Copenhagen, Denmark, 11-15 June 2017; University of Copenaghen: Copenaghen, Denmark, 2017. OP38. p. 27.

115. Keeffe, E. Classification of citrus fruit with ensemble techniques. In Proceedings of the 18th International Conference on Near Infrared spectroscopy - NIR Spectroscopy at Work in Industry (Program Book), Copenhagen, Denmark, 11-15 June 2017; University of Copenaghen: Copenaghen, Denmark, 2017. OP42. p. 27.

116. Shawky, E.; Selim, D.A. NIR spectroscopy-multivariate analysis for discrimination and bioactive compounds prediction of different Citrus species peels. Spectrochim. Acta Part A Mol. Biomol. Spectrosc. 2019, $219,1-7$. [CrossRef]

117. Lorente, D.; Escandell-Montero, P.; Cubero, S.; Gómez-Sanchis, J.; Blasco, J. Visible-NIR reflectance spectroscopy and manifold learning methods applied to the detection of fungal infections on citrus fruit. J. Food Eng. 2015, 163, 17-24. [CrossRef]

118. Blasco, J.; Lorente, D.; Cortes, V.; Talens, P.; Cubero, S.; Munera, S.; Aleixos, N. Application of near infrared spectroscopy to the quality control of citrus fruits and mango. Nir News 2016, 27, 4-7. [CrossRef]

119. Thanapase, W.; Suttiwijitpukdee, N.; Kaewcheenchai, R.; Kasemsumran, S.; Saranwong, S.; Kawano, S. Feasibility study for non-invasive detection of fruit fly eggs and larvae in intact mangoes using a hand-held near infared instrument. In Proceedings of the 14th ICNIRS Conference, Bangkok, Thailand, 7-12 November 2009; pp. 299-303.

120. Kikuchi, K.; Nakamura, T.; Taira, E. Relationships of flavour and quality of the Keitt mango. In Proceedings of the 14th ICNIRS Conference, Bangkok, Thailand, 7-12 November 2009; pp. 265-269.

121. Teerachaichayut, S.; Thanapase, W.; Kasemsumran, S.; Shigefuji, K.; Kiji, K.; Nitta, Y.; Saranwong, S.; Kawano, S. The methods of illumination and scanning for detecting internal disorders and quality of mango steen by near infrared spectroscopy. In Proceedings of the 14th ICNIRS Conference, Bangkok, Thailand, 7-12 November 2009; pp. 219-223.

122. Amodio, M.L.; Tsouvaltzis, P.; Babellahi, F.; Colelli, G. Rilevamento precoce di danni da freddo durante la conservazione di frutti di melanzana. In Proceedings of the Atti del 8th Simposio Italiano di Spettroscopia NIR, Genova, Italy, 30-31 May 2018; p. 25.

123. Subedi, P.P.; Khatiwada, B.P.; Walshaand, K.B.; Plagnol, P. A bad apple in the barrel? -Apple internal defect detection using NIR transmittance spectroscopy. In Proceedings of the NIR 2013-Picking up Good Vibrations, 16th International Conference on Near Infrared Spectroscopy, La Grande-Motte, France, 2-7 June 2013; pp. 153-155.

124. Zhou, W.; Zhang, J. Algorithms research of near infrared spectral database of apples. J. Near Infrared Spectrosc. 2015, 23, 343-352. [CrossRef]

125. Schmutzler, M.; Huck, C.W. Automatic sample rotation for simultaneous determination of geographical origin and quality characteristics of apples based on near infrared spectroscopy (NIRS). Vib. Spectrosc. 2014, 72, 97-104. [CrossRef]

126. Nouri, M.; Gorretta, N.; Roger, J.M.; Vaysse, P. Early detection of the fungal disease "apple scab" using hyperspectral imaging. Data Brief 2018, 16, 967-971. [CrossRef] [PubMed]

127. Sun, J.; McGlone, A.; Künnemeyer, R.; Tomer, N. NIR transmission and multi-laser systems for detecting vascular browning in apples. In Proceedings of the 18th International Conference on Near Infrared spectroscopy-NIR Spectroscopy at work in Industry (Program Book), Copenhagen, Denmark, 11-15 June 2017 ; p. 41.

128. Jannok, P.; Kamitani, Y.; Kawano, S. Development of a common calibration model for determining the brix value of intact apple, pear and persimmon fruits by near infrared spectroscopy. J. Near Infrared Spectroscopy. 2014, 22, 367-373. [CrossRef]

129. Che, W.; Sun, L.; Zhang, Q.; Tan, W.; Ye, D.; Zhang, D.; Liu, Y. Pixel based bruise region extraction of apple using VIS-NIR hyperspectral imaging. Comput. Electron. Agric. 2018, 146, 12-21. [CrossRef]

130. Bobelyn, E.; Serban, A.S.; Nicu, M.; Lammertyn, J.; Nicolai, B.M.; Saeys, W. Postharvest quality of apple predicted by NIR-spectroscopy: Study of the effect of biological variability on spectra and model performance. Postharvest Biol. Technol. 2010, 55, 133-143. [CrossRef] 
131. Grandón, S.; Sanchez-Contreras, J.; Torres, C.A. Prediction models for sunscald on apples (Malus domestica Borkh.) cv. Granny Smith using Vis-NIR reflectance. Postharvest Biol. Technol. 2019, 151, 36-44.

132. Bertone, E.; Venturello, A.; Leardi, R.; Geobaldo, F. Prediction of the optimum harvest time of 'Scarlet' apples using DR-UV-Vis and NIR spectroscopy. Postharvest Biol. Technol. 2012, 69, 15-23. [CrossRef]

133. Shuaibua, M.; Suk Leea, W.; Schuellerb, J.; Gaderc, P.; Hongd, Y.K.; Kimd, S. Unsupervised hyperspectral band selection for apple Marssonina blotch detection. Comput. Electron. Agric. 2018, 148, 45-53. [CrossRef]

134. Sinnaeve, G.; Pissard, A.; Pierna, J.A.F.; Lognay, G.; Rondia, A.; Dupont, P.; Donis, T.; Baeten, V.; Mouteau, A.; Romnée, J.M.; et al. Use of near infrared spectroscopy for the determination of internal quality of entire apples. In Proceedings of the 14th ICNIRS Conference, Bangkok, Thailand, 7-12 November 2009; pp. 255-259.

135. Peshlov, B.N.; Dowell, F.E.; Drummond, F.A.; Donahue, D.W. Comparison of three near infrared spectrophotometers for infestation detection in wild blueberries using multivariate calibration models. J. Near Infrared Spectrosc. 2009, 17, 203-212. [CrossRef]

136. Oliveri, P.; López, M.I.; Casolino, M.C.; Bagnasco, L.; Lanteri, S.; Medini, L. Caratterizzazione di olive taggiasche in salamoia mediante un metodo di modellamento di classe basato su PLS. In Proceedings of the Atti del 6th Simposio Italiano di Spettroscopia NIR, Modena, Italy, 28-30 May 2014; pp. 178-183.

137. Moscetti, R.; Haff, R.P.; Stella, E.; Contini, M.; Monarca, D.; Cecchini, M.; Massantini, R. Feasibility of NIR spectroscopy to detect olive fruit infested by Bactrocera oleae. Postharvest Biol. Technol. 2015, 99, 58-62. [CrossRef]

138. Pérez-Marin, D.; Adame-Siles, J.A.; Müller, F.S.; Molina, F.M.; Varo, A.G. Fine-tuning and cloning of a fiber-optic probe for in situ monitoring and evaluation of quality of olive oil products. In Proceedings of the 18th International Conference on Near Infrared spectroscopy, Copenhagen, Denmark, 11-15 June 2017; pp. 115-122.

139. Bagnasco, L.; Casolino, M.C.; Casale, M.; Lanteri, S.; Cosulich, M.E.; Pistarino, E.; De Costa, N.; Medini, L. Modellamento di classe per la discriminazione delle olive da tavola di cultivar Taggiasca mediante la spettroscopia nel vicino infrarosso. In Proceedings of the Atti IV Simposio Italiano di Spettroscopia NIR, Sestri Levante, Italy, 13-14 May 2010; pp. 140-145.

140. Oliveri, P.; Casolino, M.C.; Casale, M.; Lanteri, S.; Medini, L.; Mare, F. Una procedura di trasferimento spettrale per l'applicazione di un unico modello di classe a spettri acquisiti con strumenti diversi per l'autenticazione di olive in salamoia. In Proceedings of the Atti 5 Simposio Italiano di Spettroscopia NIR, Legnaro, Italy, 26-28 September 2012; pp. 16-22.

141. Rittiron, R.; Narongwongwattana, S.; Pookpul, K.; Choonui, W.; Boonprako, U. Nondestructive detection of watercore damage in asian pear by near infrared spectroscopy. In Proceedings of the 14th ICNIRS Conference, Bangkok, Thailand, 7-12 November 2009; pp. 271-275.

142. Uwadaira, Y. NIR and 1H NMR statistical hetero spectroscopy for nondestructive quality evaluation of peaches. In Proceedings of the 18th International Conference on Near Infrared spectroscopy-NIR Spectroscopy at work in Industry (Program Book), Copenhagen, Denmark, 11-15 June 2017; p. 22.

143. Li, J.; Chen, L.; Huang, W. Detection of early bruises on peaches (Amygdalus persica L.) using hyperspectral imaging coupled with improved watershed segmentation algorithm. Postharvest Biol. Technol. 2018, 135, 104-113. [CrossRef]

144. Jun, S.; Xin, Z.; Xiaohong, W.; Bing, L.; Jifeng, S. Research and analysis of cadmium residue in tomato leaves based on WT-LSSVR and Vis-NIR hyperspectral imaging. Spectrochim. Acta Part A Mol. Biomol. Spectrosc. 2019, 212, 215-221.

145. Hill, G.N.; Evans, K.J.; Beresford, R.M.; Dambergs, R.G. Near and mid-infrared spectroscopy for the quantification of botrytis bunch rot in white wine grapes. J. Near Infrared Spectrosc. 2013, 21, 467-475. [CrossRef]

146. Ribeiro, L.P.D.; Monteiro da Silva, A.P.; de Lima, A.A.; de Oliveira Silva, E.; Rinnan, A.; Pasquini, C. Non-destructive determination of quality traits of cashew apples (Anacardium occidentale L.) using a portable near infrared spectrophotometer. J. Near Infrared Spectrosc. 2016, 24, 77-82. [CrossRef]

147. Jannok, P.; Kamitani, Y.; Hironaka, K.; Shibayama, M.; Kawano, S. Development of a near infrared calibration model with temperature compensation using common temperature-difference spectra for determining the Brix value of intact fruits. J. Near Infrared Spectrosc. 2017, 25, 26-35. [CrossRef] 
148. Lia, X.; Weia, Y.; Xub, J.; Fenga, X.; Wuc, F.; Zhoua, R.; Jina, J.; Xua, K.; Yud, X.; Hea, Y. SSC and pH for sweet assessment and maturity classification of harvested cherry fruit based on NIR hyperspectral imaging technology. Postharvest Biol. Technol. 2018, 143, 112-118. [CrossRef]

149. Masithoh, R.E.; Haff, R.; Kawano, S. Determination of soluble solids content and titratable acidity of intact fruit and juice of satsuma mandarin using a hand-held near infrared instrument in transmittance mode. J. Near Infrared Spectrosc. 2016, 24, 83-88. [CrossRef]

150. Fan, G.; Zha, J.; Du, R.; Gao, L. Determination of soluble solids and firmness of apples by Vis/NIR transmittance. J. Food Eng. 2009, 93, 416-420. [CrossRef]

151. Olarewaju, O.O.; Magwaza, L.S.; Nieuwoudt,H.; Poblete-Echeverría, C.; Fawole, O.A.; Tesfay, S.Z.; Opara, U.L. Model development for non-destructive determination of rind biochemical properties of 'Marsh' grapefruit using visible to near-infrared spectroscopy and chemometrics. Spectrochim. Acta Part A Mol. Biomol. Spectrosc. 2019, 209, 62-69. [CrossRef] [PubMed]

152. Amodio, M.L.; Piazzolla, F.; Colelli, G. Uso di immagini iperspettrali per predire solidi solubili, $\mathrm{pH}$, acidità titolabile, fenoli e attività antiossidante di uva da tavola (cv. Italia). In Proceedings of the Atti del 6th Simposio Italiano di Spettroscopia NIR, Modena, Italy, 28-30 May 2014; p. 138.

153. Van Beers, R.; Aernouts, B.; Watté, R.; Schenk, A.; Nicolaï, B.; Saeys, W. Evolution of VIS/NIR bulk optical properties of apple skin and flesh during fruit maturation. In Proceedings of the 17th International Conference on Near Infrared spectroscopy, Foz do Iguassu, Brazil, 18-23 October 2015; pp. 74-78.

154. Giovenzana, V.; Beghi, R.; Brancadoro, L.; Guidetti, R. Sperimentazione di un sistema NIR per la valutazione dello stato sanitario di uva al conferimento in cantina. In Proceedings of the Atti del 7th Simposio Italiano di Spettroscopia NIR, Milano, Italy, 12-14 October 2016; pp. 23-28.

155. Li, X.; Huang, J.; Xiong, Y.; Zhou, J.; Tan, X.; Zhang, B. Determination of soluble solid content in multi-origin 'Fuji' apples by using FT-NIR spectroscopy and an origin discriminant strategy. Comput. Electron. Agric. 2018, 155, 23-31. [CrossRef]

156. Arendse, E.; Fawole, O.A.; Magwaza, L.S.; Nieuwoudt, H.; Opara, U.L. Evaluation of biochemical markers associated with the development of husk scald and the use of diffuse reflectance NIR spectroscopy to predict husk scald in pomegranate fruit. Sci. Hortic. 2018, 232, 240-249. [CrossRef]

157. Amodio, M.L.; Ceglie, F.; Chaudhry, M.A.; Piazzolla, F.; Colelli, G. Potenzialità della spettroscopia NIR di discriminare tra diversi sistemi produttivi e di predire la qualità alla raccolta: Caso studio su fragole. In Proceedings of the Atti del 7th Simposio Italiano di Spettroscopia NIR, Milano, Italy, 12-14 October 2016; p. 34.

158. Magwaza, L.S.; Landahl, S.; Cronje, P.J.R.; Nieuwoudt, H.H.; Mouazen, A.M.M.; Nicolaï, B.M.; Terry, L.A.; Opara, U.L. The use of Vis/NIRS and chemometric analysis to predict fruit defects and postharvest behaviour of 'Nules Clementine' mandarin fruit. Food Chem. 2014, 163, 267-274. [CrossRef]

159. Rivera, N.V.; Sanchis, J.G.; Pérez, J.C.; Carrasco, J.J.; Giraldo, M.M.; Lorente, D.; Cubero, S.; Blasco, J. Early detection of mechanical damage in mango using NIR hyperspectral images and machine learning. Biosyst. Eng. 2014, 122, 91-98. [CrossRef]

160. Barzaghi, S.; Grassi, M.; Beccari, F.; Cattaneo, T.M.P. A portable microNIR instrument as a useful screening tool in discriminating between conservation conditions applied to preserve pear samples cv Conference. In Proceedings of the NIR 2013-Picking up Good Vibrations, 16th International Conference on Near Infrared Spectroscopy, La Grande-Motte, France, 2-7 June 2013; pp. 135-141.

161. Vanoli, M.; Rizzolo, A.; Grassi, M.; Spinelli, L.; Eccher Zerbini, P.; de Azevedo Pimentelean, R.M.; Torricellia, A. Quality of Brazilian mango fruit in relation to optical properties non-destructively measured by time-resolved reflectance spectroscopy. In Proceedings of the NIR 2013-Picking up Good Vibrations, 16th International Conference on Near Infrared Spectroscopy, La Grande-Motte, France, 2-7 June 2013; pp. 177-181.

162. Magwaza, L.S.; Opara, U.L.; Nieuwoudt, H. NIR spectroscopy applications for internal and external quality analysis of citrus fruit-A review. Food Bioprocess Technol. 2012, 5, 425-444. [CrossRef]

163. Zhang, B.; Dai, D.; Huang, J.; Zhou, J.; Gui, Q.; Dai, F. Influence of physical and biological variability and solution methods in fruit and vegetable quality nondestructive inspection by using imaging and near-infrared spectroscopy techniques: A review. Crit. Rev. Food Sci. Nutr. 2018, 58, 2099-2118. [CrossRef]

164. Sánchez, M.T.; Pérez-Marín, D.; Torres, I.; Gil, B.; Garrido-Varo, A.; De la Haba, M.J. Use of NIRS technology for on-line measurement of nitrate content and other internal quality parameters in intact summer squash for baby food production. Postharvest Biol Technol 2017, 125, 122-128. [CrossRef] 
165. Srivichien, S.; Terdwongworakul, A.; Teerachaichayut, S. Quantitative prediction of nitrate level in intact pineapple using Vis-NIRS. J. Food Eng. 2015, 150, 29-34. [CrossRef]

166. AACCI Method 39-00.01. Near-Infrared Methods-Guidelines for Model Development and Maintenance, Approved Methods of Analysis, 11th ed.; AACC International, AACCI Headquarters: St. Paul, MN, USA, 1999; ISBN 978-1-891127-68-2.

167. ElMasry, G.; Da-Wen, S. Principles of hyperspectral imaging technology. In Hyperspectral Imaging for Food Quality Analysis and Control; Da-Wen, S., Ed.; Elsevier Inc.: Amsterdam, The Netherlands; Academic Press: Cambridge, MA, USA, 2010; pp. 3-43.

168. Sánchez, M.T.; Pérez-Marín, D. Non-destructive measurement of fruit quality by NIR spectroscopy. In Advances in Post-Harvest Treatments and Fruit Quality and Safety; Vázquez, M., Ramírez, J.A., Eds.; Nova Science Publishers, Inc.: Hauppauge, NY, USA, 2011; pp. 101-163.

169. Pasquini, C. Near infrared spectroscopy: A mature analytical technique with new perspectives. A review. Analytica Chimica Acta 2018, 1026, 8-36. [CrossRef]

170. Arendse, E.; Fawole, O.A.; Magwaza, L.S.; Opara, U.L. Non-destructive prediction of internal and external quality attributes of fruit with thick rind: A review. J. Food Eng. 2018, 217, 11-23. [CrossRef]

171. Yan, H.; Siesler, H.W. Hand-held near-infrared spectrometers: State-of-the-art instrumentation and practical applications. Nir News 2018, 29, 8-12. [CrossRef]

172. Porep, J.U.; Kammerer, D.R.; Carle, R. On-line application of near infrared (NIR) spectroscopy in food production. Trends Food Sci. Tech. 2015, 46, 211-230. [CrossRef]

173. Teixeira dos Santos, C.A.; Lopo, M.; Páscoa, R.N.M.J.; Lopes, J.A. A review on the applications of portable near-infrared spectrometers in the agro-food industry. App. Spectrosc. 2013, 67, 1215-1233. [CrossRef] [PubMed]

174. Tsenkova, R. Visible-near infrared perturbation spectroscopy: Water in action seen as a source of information. In Proceedings of the 12th International Conference on Near-Infrared Spectroscopy, Auckland, New Zealand, 9-15 April 2005; pp. 607-612.

175. Tsenkova, R. Aquaphotomics: Water in the biological and aqueous world scrutinised with invisible light. Spectrosc. Eur. 2010, 22, 6-10.

176. Tsenkova, R.; Muncan, J.; Pollner, B.; Kovacs, Z. Essentials of aquaphotomics and its chemometrics approaches. Front. Chem. 2018, 6. [CrossRef] [PubMed] 